

\title{
Mitigation Models and Strategies Corona Virus Disease 2019 (COVID- 19) Non-Natural Disasters (Study on BPBD of West Kalimantan Province)
}

\author{
UI Qadri1 ${ }^{*}$, Sri Syahbanita Elida ${ }^{2}$ Fitri Larasati ${ }^{3}$ \\ 1²3Politeknik Negeri Pontianak, Indonesia, \\ Email: akhiulqadri@gmail.com , srisyabanitaelida@gmail.com , anistya.fl@gmail.com
}

Abstract. Covid-19 is a non-natural disaster that has shocked countries in the world since the end of 2019 until now and its spread has not been controlled, various efforts have been made by the virus pandemic countries including Indonesia. Its spread occurs in almost every province in Indonesia, one of which is West Kalimantan Province. To prevent the spread of the virus, regional disaster management agencies (BPBD), with various parties, undertake mitigation of its spread and efforts to heal trauma during the pandemic. This study aims to determine the models and strategies of BPBD in mitigation, trauma healing efforts carried out during the pandemic and to find out the obstacles of BPBD in mitigation in West Kalimantan Province. The method used is descriptive qualitative, data sources obtained from interviews with informants, observation and documentation. The analysis technique uses an interactive model by reducing, presenting, drawing conclusions and verification. The results of this study produce models and strategies for mitigating non-natural disasters with a collaborative strategy and a pentahelix approach. Trauma healing efforts have been carried out to provide understanding to the community with preventive measures. The obstacles faced in mitigation include the low level of public awareness in maintaining health protocols and the lack of incomplete SWAB equipment in every district / city.

Keywords: Models; Strategies; Covid-19; Mitigation

Received: 23-05-2021 Revised:12-06-2021 Accepted:26-06-2021

\section{INTRODUCTION}

Micro Every country in the world must have experienced a disaster, any country would not want a disaster. Disaster is a series or event whose existence can disrupt and threaten ecosystems, both the life and livelihood of the community. This is caused by both natural, non-natural and human factors themselves, so that they can cause casualties, natural, environmental, social, economic damage and many other impacts resulting from the so-called disaster. According to the Big Indonesian Dictionary, disaster has the meaning of something that causes or causes distress, loss or suffering. Meanwhile, natural disasters are disasters caused by nature (Purwadarminta, 2006). Meanwhile, according to (Kamadhis, 2007), natural disasters are disasters caused by events or a 
series of events caused by natural phenomena that can result in environmental damage, material losses, and human casualties. One of the non-natural disasters that have shocked countries in the world since the end of 2019 until now is the widespread outbreak of the corona virus disease 2019 or known as the corona virus (covid-19). According to the www.merdeka.com page, this virus first appeared in the Chinese city of Wuhan. The origin of COVID-19 is still a mystery. Although COVID19 has no clear origin, the spread of this virus has seized the world's attention and has made Covid19 a disaster that must be immediately overcome.

The spread of covid-19 is spreading so fast, based on data from https://www.worldometers.info/coronavirus/ which can be updated at any time, it shows that the spread of covid-19 in every country continues to increase. This of course has a great influence on the order of human life, and has an impact on all sectors, especially the socio-economic community in the world. To make matters worse, there is no anti-virus to treat COVID-19. So far, its spread is almost natural to countries in the world, including in Indonesia.The Indonesian government has also designated COVID-19 as a national disaster that is included in the non-natural disaster category. According to Law No. 24 of 2007. Non-natural disasters are disasters caused by nonnatural events or series of events which include technological failures, failed modernization, epidemics and disease outbreaks. With the designation as a national disaster, making covid-19 the main concern of the government and the community, so that the spread of covid-19 does not spread and cause casualties, especially since Indonesia is an archipelagic country which has an area that is directly adjacent to countries that also have cases of COVID-19.

Almost every region in Indonesia has COVID-19 cases. Several regions in Indonesia have Covid-19 cases spread across 33 provinces in Indonesia. The spread of COVID-19 cases and the latest developments can be accessed through the official portal of the Ministry of Health of the Republic of Indonesia which can be updated at any time. Thus, of course, it is a shared responsibility to handle the spread of COVID-1 so that its spread can be minimized. One of the efforts that can be done in breaking the chain of the spread of COVID-19 is to carry out disaster mitigation that can be carried out as early as possible by the government, be it the central, regional and community. The psychological impact caused by Covid-19 is psychological disorders, depression and trauma to non-natural disasters Covid-19. This becomes a serious problem when there is no trauma healing carried out by the government which can cause concern for people affected by COVID-19. Trauma Healing is an action taken to help others to reduce or even eliminate the psychological disorders that are being experienced due to shock or trauma experienced due to a disaster, both natural and non-natural disasters. The Covid-19 non-natural disaster has a very 
broad impact, not only on health, the psychological impact caused by COVID-19 is felt by both people who are positively exposed to the virus and the community in general.

Trauma healing is a familiar term among observers in the field of disaster, especially in the field of psychology. Its existence is an attempt to provide therapy to disaster victims so as not to experience trauma from the disaster they experienced. The definition of trauma healing is a method of recovery or healing for psychological disorders experienced by a person, due to weak resilience of mental functions (Mendatu, 2010). The West Kalimantan Provincial Government through the Regional Disaster Management Agency continues to strive to tackle the COVID-19 outbreak. These efforts are guided by Law Number 24 of 2007 concerning disaster management. As an agency that handles disasters in the region, BPBD certainly seeks to carry out the mandate of the law with the aim of being able to cope with and minimize the occurrence of disasters with the models and strategies that have been carried out. Data from the Ministry of Health.go.id related to the spread of Covid-19 data in West Kalimantan Province, including the task force that was responsive to the Covid-19 response. This can be seen from the data which states that the development of COVID19 cases in West Kalimantan Province is fluctuating, meaning that cases of COVID-19 sometimes increase and sometimes there is a decline. However, non-natural disaster mitigation needs to be carried out to minimize the impact of the spread of COVID-19. Based on the description of the background, the problems raised in this study include 1). How are BPBD Models and Strategies in mitigating the Covid-19 disaster in West Kalimantan Province, 2). How is the trauma healing effort carried out by BPBD during the covid-19 pandemic, 3). What are the obstacles to BPBD in mitigating the COVID-19 disaster in West Kalimantan Province?

Previous research serves to provide an overview, analysis and enrichment, distinguishing it from the current research. This study includes several previous journals/research related to models and strategies. The previous journals/research include: 1). Setya Winarno in his journal "Houses Seismic Vulnerability and Strategic Mitigation Case of Yogyakarta City explains that the lack of awareness of the people of Yogyakarta about the vulnerability of the earthquake threat is very high, but there are still many house reconstructions using heavy building materials, the results of this study show that $84.8 \%$ of houses in Yogyakarta are non-engineered houses and very vulnerable to earthquakes. 2) Loretta Pyles, "Community Organizing for Post-disaster Social Development Locating Social Work", in the Journal describes social work interventions in disasters that focus on ways, steps in handling events that can affect individuals, families, organizations and communities. Traumatic stress is an area of concern. Besides that, human resources, people who lack understanding and vulnerability can be coordinated and synergized in disaster management. 3). 
Research "Decision Support System for Provision of Flood Disaster Logistics Assistance in Central Java Based on the Analytical Hierarchy Process". This study discusses the flood disaster which is the most frequent disaster every year in Central Java Province, this study builds a decision support system (SPK) for flood disaster logistics supplies in Central Java. The system is built using the Analytical Hierarchy Process (AHP) method and is web-based. The difference between this study and previous studies is that this study examines the Corona Virus Disease 2019 Non-Natural Disaster Mitigation Model and Strategy (Study at the Regional Disaster Management Agency of West Kalimantan Province). The most fundamental difference from the studies above is that this research examines the forms of activities, steps, models, strategies and efforts to manage nonnatural disasters. While previous research focused on the form and management of disasters. In addition, the most striking difference is in the institutional aspect, as well as the object of research. According to Law Number 24 of 2007 Article 1 point 1 disaster is a series of events that threaten and disrupt people's lives and livelihoods caused, both by natural and or non-natural factors as well as human factors, resulting in loss of life, environmental damage, loss of property. objects, psychological impacts and other impacts, both social and economic.

The definition of disaster according to the International Strategy for Disaster Reduction (Nurjanah et al, 2011) is "an event, caused by nature or due to human activities, occurs suddenly or slowly, causing loss of human life, property and environmental damage. This incident is beyond the capacity of the community with all its resources. Disaster management according to Nurjanah (2011) the operation of disaster management functions such as planning, organizing, actuating, and controlling is a dynamic process that includes prevention, mitigation, and preparedness for emergency response and recovery. The general objectives of disaster management are as follows: (1) Prevent and limit the number of human victims and damage to property and the environment; (2) Eliminate misery and difficulties in the lives and livelihoods of victims; (3) Returning disaster victims from the shelter/evacuation area to the area of origin if possible or relocating to a new area that is livable and safe; (4) Restore the functions of main public facilities, such as communication/transportation, drinking water, electricity, and telephones, including restoring the economic and social life of the disaster-affected areas; (5) Reduce further damage and loss; (6) Laying out the necessary foundations for the implementation of rehabilitation and reconstruction activities in the context of development.

Law of Number 24 of 2007 Article 13 concerning Disaster Management, namely: (1) Formulation and stipulation of policies for disaster management and handling of refugees by acting quickly and precisely as well as effectively and efficiently. (2) Coordinate the implementation of 
disaster management activities in a planned, integrated, and comprehensive manner starting from the central to regional levels to coordinate with each other

According to (David, 2011) defines strategic management as the knowledge and art of formulating, implementing, and evaluating cross-functional decisions that make an organization achieve its vision, mission and goals. Meanwhile, Hubeis \& Najib, 2008 strategic management is a set of managerial actions and decisions in determining organizational performance according to a certain period of time. From the above definition it can be concluded that strategic management is a collection of managerial decisions and actions made by top management in order to achieve organizational goals which include the formulation, implementation and evaluation of strategic plans.

Trauma Healing is a traumatic event that is defined as an abnormal mental state and/or behavior as a result of mental stress or human physical injury. In general, trauma means injury or shock. The main cause of trauma is a phenomenon where the pressure felt by a person causes deep scars, occurs suddenly, unexpectedly and beyond the control / control of the community, even often occurs and endangers life or threatens life. This event is so soul-shaking, painful and beyond the stressful situations experienced in daily life. This event is known as a traumatic event. In actions to treat and treat victims of natural disasters referred to in the theory of Tauma Healing, it aims to respond and provide actions to minimize events. In the review of cognition, roles and perceptions and social behavior are used to identify and identify the human psyche in general and in more detail.

\section{METHODS}

This study uses a descriptive qualitative approach. This approach was chosen because the main purpose of the research is to seek, understand, describe, and analyze in more depth the phenomena being researched. The focus of this research is to find out the models and strategies used by the BPBD of West Kalimantan Province in mitigating non-natural disasters COVID-19 which includes steps, efforts, models, and strategies for disaster mitigation. The research location is at the Regional Disaster Management Agency and the West Kalimantan Provincial Health Office as well as the parties involved in mitigating non-natural disasters COVID-19. The sources of data in this study are: 1) Informants, the words and actions of the informants who are observed or interviewed are the main sources in this study, 2). Documents or written sources, documents or written sources are used in research as a source of data to test, interpret, and even predict the phenomenon of the research itself, 3). Places and events as additional data sources are carried 
out through direct observation of places and events related to the strategic role of sub-districts in public services.

The data collection techniques that the author does by conducting observations, interviews, collecting materials or documented data and literature study. Observations were carried out by directly observing the basic handling process carried out by BPBD related to the covid-19 case, while the informants in this study were the mitigation and disaster section of the West Kalimantan Province BPBD who understood the problems of mitigation and disaster. Data processing in this study was carried out by collecting data (Field Notes) sourced from direct interviews, updating data from BPBD, mass media, then researchers recording all data objectively and as they were in accordance with the results of observations and interviews in the field. Data reduction is done by processing and selecting relevant data and information. Then the data is presented by compiling the main points so that conclusions can be drawn into a description of the data that describes the research problem.

\section{RESULTS AND DISCUSSION}

\section{Model and Strategy}

A model is a reflection, a representation of a real system or an abstraction from the real world that is simplified so that only important parameters appear, which can describe the relationship between parameters both qualitatively and quantitatively. An object, situation, system and event are a reflection and abstraction of a system. More broadly, a model is something that reveals and explains the relationship of various components, actions, reactions and causes and effects (Maryani \& Syamsudin, 2009)

Significant developments related to understanding of disaster management models. Through certain cycles and conventional approaches, as well as efforts and strategies in disaster management. Based on this model and strategy, disaster management is considered as a series of sequential actions or a gradual series. In this model, disaster management occurs in stages, sequentially. The focus is more on activities immediately before and after the occurrence of a disaster or mitigation event.

The next model, known as the Crunch Model, also known as the crunch model, is one of the models in disaster management. According to the crunch model, disaster occurs only when a hazard or threat impacts vulnerable people. A disaster occurs when the two elements, namely threat and vulnerability meet. A natural phenomenon by itself is not a disaster (Setyowati et al., 2012). Similarly, a population may be vulnerable for years, but without a "trigger event", there is no 
disaster. Therefore, we can see that pressure vulnerabilities rooted in socio-economic and political processes are built up and must be addressed or released to reduce disaster risk. This process can include poverty, discrimination and age-related exploitation based on sex, ethnicity, and religious factors. The result will be safe as opposed to unsafe conditions, resilient or capable communities as opposed to vulnerable communities and sustainable livelihoods as opposed to unsustainable livelihoods. The disaster mitigation learning model is a learning model whose operations use the flow: (1) preparation before the disaster takes place, (2) assessing disaster hazards, (3) disaster management, in the form of rescue, rehabilitation, and relocation, (4) providing knowledge, understanding and skills behavior in preventing, (5) detecting and anticipating disasters effectively can be transformed, and (6) socializing (Agustina et al. 2013).

The strategy for stakeholders in a disaster management organization is a large-scale, futureoriented plan to interact with competitive conditions to achieve organizational goals. Strategy is a structured and organized plan, although there are no activities detailing all future use of resources (human, financial and material), but the plan becomes a framework for overall managerial decisions. Strategy reflects the organization's knowledge of how, when, and where the organization will compete and for what purposes the organization should compete. Strategy has several characteristics, including unified (unified) which unites all parts of the company, comprehensive (comprehensive), which includes all aspects of the organization, and integral (integrated), all strategies will be suitable or in accordance with all levels within the organization. In the organizational cycle, the strategy consists of three stages, namely formulation, implementation, and evaluation.

The aim of using mitigation strategies in communities related to the transmission of Covid19 is to slow the transmission of the disease and to protect individuals who are at higher risk for severe disease, including older adults and people of all ages with underlying health conditions and health workers and critical infrastructure workforce. These approaches are used to minimize the morbidity and mortality as well as the social and economic impacts caused by COVID-19. In disaster mitigation there is also a community mitigation strategy where individuals, communities, business elements and health service organizations are inseparable in handling and mitigation.

These strategies must be applied to prepare the community when there is evidence of Covid19 transmission in the community. Early warnings related to the transmission of COVID-19 in the community include, among others, the detection of confirmed cases of COVID-19 without an epidemiological relationship with tourists or previously known cases or more than three levels of transmission contact. Some of the activities included in the mitigation strategy include: 
1) Emphasize individual responsibility to implement personal-level actions that may/should not be done.

2) Empowering businesses, schools, and community organizations to implement the recommended actions, especially by protecting people who are at high risk of infection with COVID-19.

3) Focus on regulations that provide essential infrastructure or services for individuals at increased risk of severe disease.

4) Minimize disturbances to daily life to be avoided as far as possible.

\section{BPBD Models and Strategies in Mitigating the Covid-19 Disaster in West Kalimantan Province}

Through the Decree of the Governor of West Kalimantan Number 444/Dinkes/2020 concerning the Task Force for the Acceleration and Handling of Covid-19 with a strategy and model of collaboration between the Regional Disaster Management Agency and the Health Office, Satpol PP and Regional Government, the Village/Urban Transportation Service in the West Kalimantan Province. together to deal with the spread of covid-19 Experts try to find the implications and ways of dealing with disasters. There are different implications in the handling carried out by the government, both central and regional, both in terms of handling and allocating resources, especially managerial resources that have not been used optimally, effectively, and efficiently, this is due to territorial, geographical differences and the character of each. each area too. This is influenced by several things. First, the effect of rapid transmission requires the Government to be able to allocate resources effectively, because the government's response is the main determinant of the final measure of how big the pandemic/epidemic disaster is. Second, covid-19 is considered different compared to other natural and non-natural disasters, the epidemic disaster/covid-19 outbreak has a dynamic nature and the periodization of time it occurs is not measurable and tends not to be easily controlled. The impact of the COVID-19 pandemic/outbreak will be directly proportional to the amount of costs that must be incurred by the Government in overcoming its spread, with the meaning of the word mistakes in political decision-making will have a major influence on the costs to overcome the Covid-19 pandemic with losses, whether it is casualties, the number exposed, and economic losses.

Based on information from the national mass media kompas.com, (Monday/2/3/2020) the President of the Republic of Indonesia, Joko Widodo, announced the first positive case of COVID19 which was allegedly transmitted through human-to-human transmission. Various efforts have 
been made by the government of the republic of Indonesia, one of which is by forming a task force to accelerate the handling of covid-19 which was ratified through Presidential Decree of the Republic of Indonesia number 7 of 2020, then updated through Presidential Decree of the Republic of Indonesia Number 9 of 2020 considering the progress and certain conditions. The objectives of this task force are to increase national resilience in the health sector, to increase synergy between ministries/agencies and local governments, to anticipate the escalation of the spread and to increase readiness, ability to prevent, detect and respond to COVID-19.

In implementing this protocol and handling COVID-19, the Task Force for the Acceleration of Handling COVID-19 as the main element and supported by all elements and the community agreed to carry out joint efforts to accelerate the handling of the COVID-19 pandemic. Carrying out emergency response to pandemics and disease outbreaks that refer to the definition of disaster is regulated in Law no. 24 of 2007 concerning disaster management. The Covid-19 pandemic and outbreak that occurred in the territory of Indonesia, included in the category of non-natural disasters, had a broad impact not only on the soul (life) but also affected the order of people's lives at large. This pandemic handling policy is also strengthened by Law no. 4 of 1984 concerning infectious disease outbreaks and Law no. 6 of 2018 concerning health quarantine.

The pandemic disaster and the COVID-19 disease outbreak have a large potential risk if comprehensive control is not carried out. The task force for the acceleration of handling COVID-19 as the executor has also designated this incident as a national disaster which was stipulated through BNPB Decree No. 13.A Year 2020 whose status will end on May 29, 2020. However, the task force for the acceleration and handling of COVID-19 can develop guidelines and frameworks for handling the pandemic based on the status and scale of the disaster. In addition, the Government at the provincial and district/city levels can then form their respective regional task forces and can use this protocol as a reference. Furthermore, the regional Covid-19 handling acceleration task force can adopt through technical guidelines or service standards.

The task force for the acceleration of handling COVID-19 has been equipped with an integrated information system called BLC (United Against Covid-19) for data analysis which is then used as the basis for recovering productive and safe community activities for COVID-19. Through this system, reporting of data from the regions to the center can be faster, to maximize performance to increase public awareness of risks and vulnerable areas around them. Based on a press release from the website www.presidenri.go.id (24 June 2020), in the press statement, Dewi Nur Aisyah, an expert in infectious disease informatics and epidemiology, said that the BLC system had recorded 39,000 (thirty-nine thousand) investigation data. epidemiology until June 2020. The 
investigation data came from People Under Monitoring (ODP), Patients Under Supervision (PDP), positive patients, close contacts of travellers obtained from Puskesmas, Hospitals (RS), and the Health Service. In addition, data from the system is also integrated with Online Hospitals under the coordination of the Director General of Health Services, Ministry of Health of the Republic of IndonesiaN.

The BLC system has been integrated with the health research and development organization system whose data has also been cleaned and cleaned by the surveillance system from the Directorate General of Disease Prevention and Control (P2P) of the Ministry of Health. The BLC system also records all logistics data, starting from warehouse data to see the availability and distribution of logistics, hospitals (RS) and laboratories including medical devices, personal protective equipment (PPE), and medicines. In addition, the BLC system also collects and integrates data and synergizes with the care and protection application in recording population mobility and is supported by the SDLC (System Development Life Cycle) model, which will be used to record travelers who will travel from one region to another so that ease in data processing.

Basically, the BLC system is the result of excellent collaboration and coordination between components of the task force for the acceleration of handling COVID-19, which is cross-ministerial, cross-institutional, cross-sectoral so that it can make it easier to analyze and make future policies. The implementation of the BLC system for the basis of recovering productive and safe community activities from COVID-19 also refers to the pillars of epidemiology. From the entire BLC system data, it is then collected, given weights, scored, and then used as a basis for whether an area or an area has a risk of increasing cases of COVID-19 in the low, medium and high categories. In this case, the government is targeting a reduction in Covid- 19 cases by up to $50 \%$, which must continue to be monitored every week, including cases of ODP (People Under Monitoring) and Patients Under Monitoring (PDP) in the community. Apart from the number of positive cases, the task force for the acceleration of handling COVID-19 also monitors data on deaths, both from positive patients, as well as ODP and PDP every week through the BLC system. The next thing to monitor is the increase in healing in an area. This cure applies to positive patients.

In handling pandemic disasters, security and safety factors are one of the keys to success in handling, considering that service providers (medical teams and humanitarian workers) also have the potential to be infected during the service delivery intervention process. On the other hand, security guarantees need to be optimized by the security forces if there is a decision that has the potential to cause unrest in the community. In ensuring security and safety that can be prepared and accompanied by competent experts in formulating policies and ensuring that mechanisms 
related to security and safety are well distributed to all parties. All those involved in the task force for the acceleration of handling COVID-19 to the frontline service providers are obliged to share relevant safety and security information without delay and without exception. If safety and security issues arise in the response process, they can be informed in real-time. If there is information on the threat of massive transmission in an area, anticipatory efforts can be carried out quickly and in a planned manner.

In handling COVID-19, it is only carried out by the National Disaster Management Agency (BNPB), the handling must involve the cooperation of all agencies, both government and private as well as all elements of the Indonesian people. Efforts to handle COVID-19 are the responsibility of all parties, collaboration through collaboration consisting of government, business institutions, communities, mass media and academics is the nation's strength in fighting the COVID-19 pandemic. This collaboration does not only stop at handling Covid-19 but must be able to continue to help people affected by natural and non-natural disasters.

The involvement of non-government actors can be one of the key elements in efforts to deal with COVID-19. The contribution of non-government actors is also an opportunity and overcomes several challenges that occur in the field. The government through the task force for the acceleration of handling COVID-19 has also identified several non-government actors as additional resources in a crisis called the pentahelix approach. Pentahelix is one of the approaches used by the government to involve 4 other non-government elements in accelerating the handling of COVID19, namely the community, academics, media, and business institutions (private). Community participation in crisis situations is the main resource in handling responses, especially as initial responders. Various forms of contributions and initiatives that have emerged in the community have become capital as part of the handling of the COVID-19 response in the community. Community involvement in handling COVID-19 can be manifested in various forms, including community/community-based activities, humanitarian volunteers and civil society organizations. As an additional resource, this community contribution can also be accommodated by the task force for the acceleration of handling COVID-19 both at the center and in the regions and can be managed based on the capacity it has. This involvement can accommodate both individually and institutionally by considering the experience, expertise, and mobilization of resources owned. The task force for accelerating the handling of Covid-19, to involve more community participation in the context of handling this Covid-19, has also encouraged the formation of a platform to map out humanitarian action in the community and manage volunteers through the volunteer desk. 
Academics from a few universities in the country have carried out several research, technical support, and education in the community since the first cases of COVID-19 spread in the community. Various studies or modeling of the impact of COVID-19 have also been launched as a foothold in the preparation of several policies both at the national and regional levels, especially in West Kalimantan. Through the task force for the acceleration of handling COVID-19 both at national and regional levels, it is possible to optimize the role of academics in accelerating the handling of COVID-19.

Media, whether in the form of print media, online, or television as a platform for conveying information, also has various functions including as a supervisor, learning media, cultural transformation, and entertainment. The media also makes a significant contribution in helping the government (task force) as a means of communication to the community as part of efforts to build awareness and prevent the spread of COVID-19. The importance of media support is also a filter to prevent the spread of false information (hoax) that occurs in the community. As an element that has duties and functions in handling COVID-19, the Task Force for the Acceleration of Handling COVID-19 has sought to optimize the involvement of the media, both electronic and mass media, in conveying messages and education related to COVID-19. To optimize and synergize, the task force for the acceleration of handling COVID-19 both at the center and in the regions has involved and participated in the media to carry out its mandate and instructions as well as coordination in preventing the spread of COVID-19.

In the Covid-19 crisis in Indonesia, business institutions also experienced a significant impact due to several policies related to access restrictions that required the temporary suspension of several economic activities. But on the other hand, business institutions to accelerate the handling of COVID-19 have also contributed quite significantly to various forms of support, either in the form of funding support, human resources, asset lending or business infrastructure. The task force for the acceleration of handling COVID-19 both at the center and in the next regions can also build cooperation with business institutions that are committed to providing support in efforts to accelerate the handling of Covid-19.

The West Kalimantan Provincial Government has also instructed Regency/City regional heads to immediately involve village heads and hamlet heads in each region to build an Alert Village which aims to prevent COVID-19. In addition, Desa Siaga also aims to realize the village so that it becomes an independent village where facilities and infrastructure, economy, social and environment can develop. So that if a case like this occurs, it is easier to handle it (Tribun Pontianak.co.id, July 20,2020). Collaboration between the government and non-government in the 
formation of alert villages in West Kalimantan in accelerating the handling of COVID-19 is urgently needed because the COVID-19 pandemic is a national epidemic. The establishment of a standby village in West Kalimantan is not only carried out by the government but must also be carried out by non-government parties. This is in accordance with a statement quoted from www.Antarakalbar.com (July 25, 2020) which stated that Pertamina formed an Alert Village in accelerating the handling of COVID-19 in West Kalimantan. The establishment of an alert village is aimed at helping the government in stopping the spread of COVID-19, especially in West Kalimantan.

Citing a source from www.kalbar.antaranews.com, (29 July 2020) the handling of covid-19 in West Kalimantan received approval from the National Disaster Management Agency (BNPB) of the Republic of Indonesia (RI). This is because the West Kalimantan Provincial Government and West Kalimantan Regional Government Organizations, especially the West Kalimantan Regional Disaster Management Agency (BPBD), are considered fast and responsive in handling COVID-19 during the pandemic. Efforts made during the pandemic are that there are standard food menus given to patients, namely honey, papaya, bananas, avocados, and boiled eggs. So that patient infected with COVID-19 can recover within 21 (twenty-one) days. In addition, rapid tests were also carried out to find out the number of patients infected with COVID-19 so that the Provincial Government of Kalimantan and West Kalimantan Regional Government Organizations, especially the West Kalimantan Regional Disaster Management Agency (BPBD) were quick to take policies related to handling / handling COVID-19 in West Kalimantan.

\section{Efforts in Trauma Healing during the covid-19 pandemic}

Trauma healing is an action taken to help others in reducing and eliminating psychological disorders experienced and caused by shock or trauma due to the occurrence of a disaster, both natural and non-natural disasters. The Covid-19 non-natural disaster has a very broad impact, not only on health, but the psychological impact also caused by COVID-19 is felt by both people who are positively exposed to the virus and the community in general. Handling psychological aspects (trauma healing) for victims of non-natural disasters COVID-19 is very important, seeing that many of those who were positively exposed and the public experienced trauma and excessive fear, especially seeing the state of the environment. In many cases of natural and non-natural disasters, trauma healing is usually applied to children and the elderly. However, for Covid-19 all ages must receive treatment in this case, both from the government and or related organizations. Stress and 
depression are the effects of disasters and programs are usually carried out in the form of trauma healing for communities affected by disasters.

Trauma healing aims to be able to rebuild the mental and psychic of the community, both those exposed to COVID-19 and society in general. During this pandemic condition, mitigation efforts must not be interrupted or run independently, but must still be integrated from promotive to rehabilitative efforts so that the heavy burden of physical health threatened by COVID-19 does not increase due to mental disorders. In addition, the trauma healing program is also a solution for people who are traumatized by the COVID-19 pandemic. These efforts include:

1) Minimize exposure to false media (hoaxes) that report on non-natural disasters covid-19

2) Avoid places where the occurrence and spread of the virus, for example avoiding crowds and crowds.

3) Provide a presentative isolation room for people who have been exposed to COVID-19, complete with adequate facilities

4) Provide support to people exposed to COVID-19 covid

5) Provide donations in the form of food, clothing, and boards.

6) Become a listener to the stories of the victims, if they are ready to tell the stories they have experienced

\section{BPBD's obstacles in mitigating the COVID-19 disaster in West Kalimantan Province}

The National Disaster Mitigation Agency (BNPB) acknowledged that the handling of COVID19 in Indonesia was hampered due to many limitations, both from medical personnel, hospitals, and medical equipment. This was also conveyed by the Deputy for Prevention of the National Disaster Management Agency, Lilik Kurniawan, who stated that this reality was exacerbated because there was no vaccine. The community and medical personnel are asked to be the front line and the last bastion in the fight against covid-19, therefore prevention is a priority, and the community and medical personnel must have the same vision and work together. In addition, there are 1,936 doctors in Indonesia, when compared to the population ratio, each doctor must serve 1.2 million people. Indonesia also has a deficit of personal protective equipment (PPE), ventilators to polymerase chain reaction (PCR). Some emergency hospitals were built suddenly to reduce the accumulation of patients.

Based on information from the West Kalimantan Regional Disaster Management Agency (BPBD), the West Kalimantan Provincial Government and West Kalimantan Regional Government Organizations are still experiencing obstacles in handling covid-19, this is marked by the increasing number of patients infected with COVID-19 starting in the last 4 months, this is due to a lack of 
public awareness in implementing health protocols, for example, there are still many people in West Kalimantan who still gather in coffee shops, restaurants, city parks and others without implementing health protocols, one of which is not wearing masks.

The dishonesty of the community is also an obstacle for the West Kalimantan Provincial Government and West Kalimantan Regional Government Organizations, especially the West Kalimantan Regional Disaster Management Agency (BPBD), so to find out whether the patient is positive or negative infected with COVID-19 is still very difficult. Even though honesty with patients is very important in handling COVID-19, so that related parties take the steps that have been set in handling it. Based on information from the West Kalimantan Provincial Health Office, the length of time spent on the results of the PCR (Polymerase Chain Reaction) swab test is also an obstacle in handling COVID-19 in West Kalimantan. This is because the PCR (Polymerase Chain Reaction) swab test can only be done at hospitals located in the provincial capital, Pontianak. As for the regencies in West Kalimantan, none of them are facilitated for PCR (Polymerase Chain Reaction) swab testing, so if you want to do the PCR swab test, samples from the related regencies must be sent to Pontianak. In addition, sample delivery is also limited, this is due to the lack of availability of reagent kits, especially at Tanjung Pura Hospital and the lack of medical personnel who handle PCR swab testing, so that priority is given to patients who are being treated, if there are people from outside who want to do PCR (Polymerase Chain Reaction) swab testing will not be served. This is also in line with what was conveyed by one of the informants who said that the problem of limiting samples was very unfortunate, because to be able to confirm whether people were positively infected with COVID-19 or not, it was by means of a PCR (Polymerase Chain Reaction) swab.

\section{CONCLUSIONS}

This study aims to examine the factors that can affect tax compliance at Tanah Abang Market traders, which are the Tax Rate, Perceived Opportunity to Evade, Legal Certainty, and Group Influence with 154 respondents. Referring to the multiple linear regression line equation, the tax rate variable positively affects tax compliance with a constant beta value of 0,062 . However, based on the results of the t-test, it states that the Tax Rate variable are not so crucial to Tanah Abang Market traders, marked by the t-count value of 1,059 , smaller than the $t$ table of 1,9760 . It indicates that regardless of the tax rate, it does not significantly affect the tax compliance of Tanah Abang market traders. 
Meanwhile, the variable Perceived Opportunity to Evade has the most dominant effect on tax compliance with a constant beta value of 0,393 . Furthermore, the Legal Certainty variable positively affects tax compliance with a constant beta value of 0,153 . It indicates that the fewer gaps in tax avoidance and the more frequent law enforcement due to the better DGT supervision model, the higher the tax compliance level of Tanah Abang Market traders. The last independent variable, Group Influence, also has a positive effect on tax compliance with a constant beta value of 0,150 . It can be concluded that the role of the surrounding environment forms an opinion to comply or not comply with the tax obligations.

Based on the above conclusions, in this study the recommendations that need to be considered for government, to be specific the tax authorities, as policymakers for PP 23/2018. It turns out that the tax rate does not have a significant impact on the compliance behaviour of taxpayers. This result is very useful for the DGT authority and the Fiscal Policy Agency as policymakers that the reduction in tax rates does not affect the compliance behavior of MSEs traders. However, the focus of the taxpayers' complaint is the MSE tax calculation scheme which is directly subject to gross turnover and ignores any losses that occur. Therefore, the DGT should make a special calculation scheme for Final Income Tax which is also simple but considers the losses that occur. Quality service does not only refer to service alone but must emphasize the process of providing the right direct service to the community (Djafar \& Radjak, 2016). Examining the results of research that prove that the Opportunity to Evade and Legal Certainty perception are the most dominant influence on the tax compliance of Tanah Abang Market traders, the DGT Authority and its operational units must increase the service quality to the MSE taxpayers by monitoring of compliance with MSE taxpayers through derivative regulations on the implementation of supervision of MSE taxpayers by recording, direct observation in the field, imposing tax fines on MSEs, and also create an integrated application to make it easier for both parties, DGT and taxpayers to pay and report tax. Based on the results of the research which proves that there is a group influence on the compliance behavior of the Tanah Abang Market Trader Taxpayer, DGT must aggressively and massively make attractive appeals and invitations to pay and report taxes. 


\section{REFERENCES}

Agustina, I Gusti Ayu Tri dan I Nyoman Tika. (2013). IPA Aspek Fisika dan Kimia. Yogyakarta: Ombak.

David, F. R. (2011). Strategic management: concepts and classes. Prentice Hall.

Djafar, L., \& Radjak, L. I. (2016). Pelayanan Publik di Kantor Desa Bulontio Barat Kecamatan Sumalata Kabupaten Gorontalo Utara. 5.

Hubeis, M., \& Najib, M. (2008). Manajemen strategik dalam pengembangan daya saing organisasi. Jakarta: PT Elex Media Komputindo.

Kamadhis, U. G. M. (2007). Eka-Cita Bersatu dalam Dharma. Buletin Kamadhis UGM Nomor. XXVII/September/2007. Kamadhis UGM, Yogyakarta.

Maryani, E., \& Syamsudin, H. (2009). Pengembangan Program Pembelajaran IPS untuk meningkatkan kompetensi Keterampilan sosial. Jurnal Penelitian, 9(1).

Mendatu, A. (2010). Parapsikologi: Sebuah pengantar singkat. Psikoeduka: Dipublikasikan Bebas.

Nurjanah, et al. (2011). Manajemen Bencana. Bandung: Alfabeta

Purwadarminta. (2006). W. J. S. Kamus Umum Bahasa Indonesia. Jakarta: Balai Pustaka

Setyowati, D. L., Amin, M., \& Astuti, T. M. P. (2012). Community Efforts For Adaptation And Anticipate To Flood Tide (Rob) In Bedono Village, District Sayung Demak, Central Java, Indonesia. Man In India, 97(5), 241-252. 